\title{
Assessment of the components that deliver agricultural extension services, at Gezira state-wad medani great locality, Sudan
}

\begin{abstract}
This study was conducted at Wad Medani Great Locality, Sudan- season 2016. The study attempts to assess the components that transferring agricultural extension services to the farmers involving services centers, also to assess the old components through the links between each other's, type of the link, and information transferring cost. The primary data were collected from a field surveys using a well-structured questionnaire. Secondary data was collected from books and scientific journals. The quota sample technique was used and 322 farmers were selected as the study population. Statistical Package for Social Sciences was used for data analysis focusing on descriptive statistics and correlation analysis. Results indicated that $64 \%$ of the respondents have landowner, $70 \%$ of their agricultural experience less than 15 years, and 79\% Invested in cotton, corn, wheat, and peanuts, and $76 \%, 68 \%$, $75 \%$, and $71 \%$ of the respondents their source of fertilizer, fertilizer information, pesticides, and pesticides information were service centers respectively. $71 \%$ of the farmers assess that their links with extension were strong- direct- official, $62 \%$ and $92 \%$ of the respondents stated the personal method was used for delivering information by extension is its and the service centers respectively. Services centers were quick response partners and extension was the less cost. Results of correlation analysis showed that the link with extension had high significant with the source of seeds (.011) $(\mathrm{R}=-.142)$, and highly significant with the source of fertilizer $(.000)$ the value $(\mathrm{R}=.317)$, fertilizer information, pesticides, and pesticides information $(.000)$ the value $(\mathrm{R}=.271)$. The result of the regression test of the farmers showed a high significant link with the extension (.487 beta). The research recommended information should be transferred to all agricultural partners; Training sessions have to be held to all extension officers and ASCs workers, using more than one approach for conducting the extension process.
\end{abstract}

Keywords: extension, model, farmers, transferring, Sudan
Volume 5 Issue 2 - 2020

\author{
Adam Elradi MAli,' Mohamed Atta Ali \\ Abdallh, ${ }^{2}$ Mohammed AA Hamad ${ }^{3}$ \\ 'Department of Agricultural Extension and Training, University \\ of Gezira, Sudan \\ ${ }^{2}$ Minstry of Agriculture, Sudan \\ ${ }^{3}$ Department of Rural Extension and Training, University of \\ Kordofan, Sudan
}

\begin{abstract}
Correspondence: Mohammed Adam.A.Hamad, Department of Rural Extension and Training, University of Kordofan, Elobeid, Sudan,Email abuitaf2013@gmail.com
\end{abstract}

Received: January 09, 2020 | Published: March 02, 2020
Abbreviations: TOT, transfer of technology; FFS, farmer field school; IPM, integrated pest management; GDP, gross domestic products; USAID, American agency for international development; ASCs, agricultural services centers; SPSS, statistical package for social sciences

\section{Introduction}

Improvement in the management of agricultural extension organizations has been identified as a key challenge in the delivery of extension services ${ }^{1}$ Over the years, several components have been shared to enhance the effectiveness of extension services and service delivery. A component defined as anybody that works out in the agricultural sector to deliver some sort of services to the farmers that aid in the agricultural process and enhance productivity positively. In this section, we attempt to describe the various models of extension and its components, ${ }^{2}$ eight basic extension models in Africa, all of them imported from other continents as listed below.

Technology transfer model: the Transfer of Technology (TOT) model it based on the assumption that transfer of technology and knowledge from scientists to farmers help in developing agriculture ${ }^{3}$ and assumes that farmers' problems can be solved by people and institutions that have this 'modern' knowledge. This model operates by the components of agricultural extension administration and some NGOs.

The public extension model: Public interest implies serving farmers and the urban population, securing subsistence production and promoting cash crops for export, reaching the masses of rural households and serving the needs of specific groups, extending assistance to high-potential and disadvantaged producers. This model operates by the component of governmental agricultural extension.

Commodity extension model: This model was pioneered among smallholders producing cotton in Mali and other Francophone countries 50 years ago. Commodity-based extension run by governments, parastatals, or private firms is the most frequent extension method. This model operates by private components that work in agricultural extension.

T\&V model: Launched in Turkey in the early 1970s and then spread to India and throughout Africa under World Bank sponsorship in the late 1970s and early 1980 s, this model has proven to be financially unsustainable. The system concentrates on contact farmers expected to pass the information on to fellow farmers with similar problems. To ensure regular field contacts, facilitate supervision and 
communication, and set clear and attainable objectives, fixed visits at regular intervals are prescribed. T \& V has increased the quantity but not the quality of extension contact and this, in turn, has increased farmers' knowledge and adoption of technology. ${ }^{4}$ This model held by so many components according to its objectives.

NGO (international and local) model: this model spread rapidly in the 1990s as many NGOs shifted gears and moved from being providers of food and humanitarian assistance to become agents of development. The NGOs established food and community development projects in many African countries in the 1990s that were primarily financed by bi-lateral donors. ${ }^{5}$ This type of extension held by NGOs and GOs components only

The Private sector model: this model has been spreading in industrial countries such as the Netherlands and New Zealand and more recently in middle-income countries such as Chile and low-income countries such as Uganda. Under this model, the farmer is expected to pay some of the cost of extension with the hope that public outlays on the extension could be reduced. ${ }^{5}$ This model works by special components that established with private sectors to serve extension purposes.

Farmer Field School (FFS) model: this started in the rice monocropping farms in the Philippines and Indonesia in the late 1980s, as a way of diffusing knowledge-intensive Integrated Pest Management (IPM) practices for rice. FFS has since been adapted to work with other crops and diseases, and has spread rapidly across Asia, Africa, and Latin America. ${ }^{6}$ The FFS uses participatory methods to help farmers develop their analytical skills, critical thinking, and creativity, and help them learn to make better decisions. Farmer Field School is a method to train adult farmers in an informal setting within their environment, and operates by the components of public extension. It is often described as a 'school without walls. FFS is a practical approach to training, which empowers farmers to be their technical experts on major aspects of localized farming systems. FFS assumes that farmers already have a wealth of knowledge. Therefore, field schools are oriented to providing the knowledge and management skills in a participatory manner, so that the farmers' experience is integrated into the program.

Innovative linkage model: historically, the extension has mainly involved technology transfer, with the village extension worker transferring knowledge from research stations to farmers by using individual, group, and mass media methods, this work operates by the component of public extension. Various approaches are being promoted but information on their impact and sustainability is sparse, ${ }^{8}$ most recently, the extension has been asked to play a 'technology development role' by linking research with community group needs and helping to facilitate appropriate technology development. virtue, rights, and utilitarian models have successive levels of priority as the theoretical base of sustainable agricultural development. ${ }^{9}$

Farming System in Sudan: divided into three main categories these are; irrigated agriculture this covers 2 million hectares extend from the river Nile \& its tributaries either by surface pump or flood irrigation system. The main crops are cotton, sugar cane, wheat, sorghum, pulses, vegetable, and fruits, green fodders. These crops contribute by 64\% of the GDP (Gross Domestic Products). Rain Fed Mechanized Farming mainly in the central clay plain of Sudan; the average rainfall ranges $400-800 \mathrm{~mm}$. The main crops are Sorghum, which covers $85 \%$ while the Sesame covers $10 \%$ of the cultivated area. The system is fully mechanized apart from weeding\& sesame cutting. The last one is traditional rain-fed farming cover 9 million hectares mainly practiced in southern \&western Sudan. The main crops are millet, Gum Arabic, sorghum, Hibiscus, watermelon\& Pigeon Pea.

The extension services started in Sudan in 1958 supported by the American Agency for international development (USAID), which assisted the Ministry of Agriculture to establish an extension department, open extension units in some regions and train extension workers in America. From 1958 up to 1981, about 17 extension units were established in different parts of the country. Currently, Agricultural extension services are provided by a variety of government department and corporations. Due to lack of evidence on some of the newer models, extension reforms, and pluralistic models that involve many different extension providers ${ }^{10}$ and higher population, most of the populations are working directly or indirectly in agricultural sector, and available of all the agricultural components (Farmers, Agricultural Services Centers (ASCs), The public extension farmers, Imports companies, Research Institution (research centers and University of Gezira) this study was suggested and amid to construct a model for transferring agricultural extension services to the farmers involving services centers, also to assessment the old model through the links between the components, type of the link, assessment of information transferring cost.

\section{Materials and methods}

\section{Area of the study}

This study is carried out in Gezira State- Wed Medani Greater Locality, lies in the center of Sudan and represents one of the largest states with higher population density, and contributes much to the agriculture of Sudan. Gezira state is located between latitude $13^{\circ} .32$ South $15^{\circ} .30^{`}$ North, and longitude $32^{\circ} .22^{`}$ West $34^{\circ} .20^{`}$ East (Annual report, 2016) Figure 1 it is neighbored by Khartoum state from the North, Sinnar State from the South, Gadarif State from the East and the White Nile State from the western side. The area of Gezira State is estimated 275.492 square kilometers, which is equivalent to less than $20 \%$ of the total area of the Sudan. The total number of the population in the Gezira State is about 4.244.000 (in the year 2009). The State comes second to Khartoum state of the population number. Wad Medani is the capital of the state, the population of Wad Medani is 386.000 (in the year 2009).

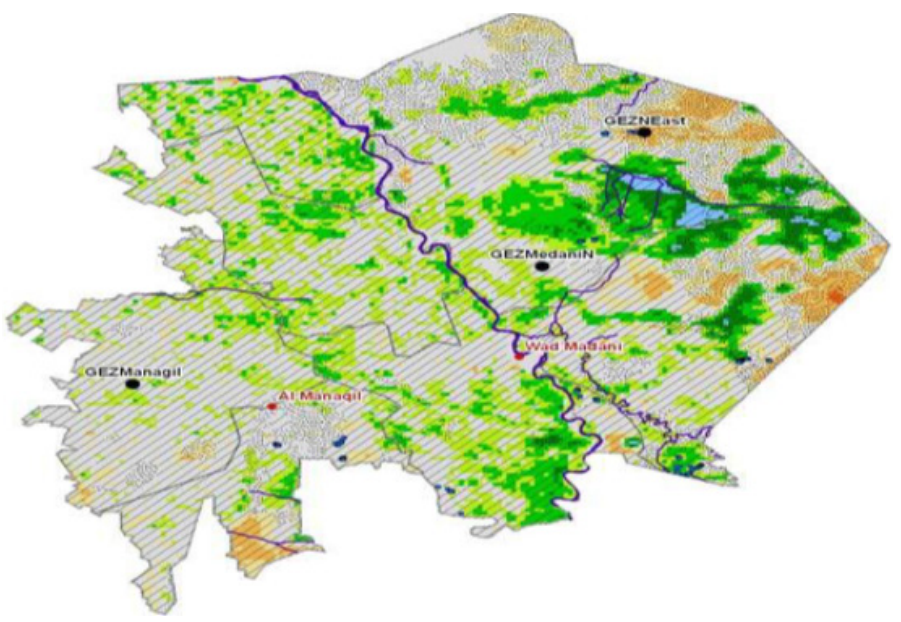

Figure I Map of Gezira State-Sudan. 
Wad Medani Greater Locality is one of eight Localities constituted Gezira State namely (Wad Medani Greater Locality, South of Gezira Locality, East of Gezira Locality, Um Elgura Locality, Elkamileen Locality, Alhasahisa Locality, Almanaqil Locality, and Al Qurashi Locality). It is a well-populated area suitable for agriculture and considered as a very important agricultural area in the State and most of the population are working directly or indirectly in the agricultural sector. In Wad Medani Greater locality there are four extension offices in the sub administrative units (Wad Medani East complexes, Hantoob complexes, Alshabarga complexes, and Fadasi complexes). ${ }^{11}$

\section{Population and sampling procedures}

Population of the Study is farmers in Wad Medani Greater Locality; those were 2000 farmers according to Agricultural managements in the Locality in season 2015-2016.

Based on Steven Samson equation a general formula for sample size selection was used as follows:

$$
n=\frac{N \times p(1-p)}{\left[N-1 \times\left(d^{2} \div z^{2}\right)\right]+p(1-p)}
$$

Source; Altae, ${ }^{12}$

Where: $\mathrm{N}=$ total population $\mathrm{n}=$ sample size $\mathrm{d}=$ =proportion of error (.05) $\mathrm{p}=$ proportion of availability of particularity and neutralization (.50) $\mathrm{z}=$ degree of the normative meeting to a level of mark 0.95 (1.96). So according to the previously mentioned equation samples size is 322 farmers selected through quota sample technique.

\section{Data collection and analysis}

The field survey was used to collect data by using a questionnaire constructed for this purpose through personal interview techniques. While secondary data collected from different sources as references, previous studies, reports, internet, and relevant sources.

The collected data was fed into the computer and statistically analyzed by using Statistical Package for Social Sciences (SPSS).
The descriptive analysis used such as percentage and frequencies distribution, Moreover Correlation and Regression analysis were used to get out the relationship and the effect between different components in the proposed model.

\section{Results and discussions}

\section{Results of descriptive analysis}

The results in a Table 1 indicated that most of the respondents $85 \%$ were males while $15 \%$ of them were females. This may be due to that the ownership of the agricultural enterprise always concerns by a man more than women, also may be due to the social traditions which high light men as the head of the household. For the more women always in traditional societies concern responsible for domestic work in their houses. $52 \%$ of the respondents fall in the age group (21-40) year, while $37 \%$ of them were a (41-60) year, which represents active age for production. Also, the result revealed that $35 \%$ of the respondents have a secondary level of education, compared to $25 \%, 20 \%, 14 \%$ and $6 \%$ there have basic, university, Khalwa and illiterate respectively. This in line with ${ }^{13}$ which cited farmers in rural area belonged to the relatively younger age and better-educated group with agriculture as the main source of income and livelihood. Concerning the land ownership the results showed that $64 \%$ owner, $24 \%$ were renters while only $12 \%$ were participants with others. The results extend to depicted that the majority of the respondents $(51 \%)$ there land size between less than 5 and less than 10 Feddan, while $33 \%$ of their land size more than 10 Feddan and only $17 \%$ of the respondents their land size less than 5 Feddan. In regards to level of income the same table shows that the high percentage of the respondents (37\%) their income level between 10.000 to 20.000 SD pounds per year, while 33\% their level of income was less than 10.000 SD pounds per year and 30\% of the respondents their income level more than 20.000 SD pounds, that means the responder includes all farmer sector (smallholder, medial holder, and the big size holder) with high, medial and lowincome level. The business of agricultural research, development, and extension (RD\&E) has undergone considerable change in developing countries moving from a domain largely dominated by government departments to a situation of multiple actors. ${ }^{14}$

Table I Distribution of the respondent's according to socioeconomic characteristics

\begin{tabular}{|c|c|c|c|}
\hline \multicolumn{2}{|c|}{ Socioeconomic characteristics } & \multirow{2}{*}{$\begin{array}{l}\text { Frequency } \\
274\end{array}$} & \multirow{2}{*}{$\begin{array}{l}\text { Percentages (\%) } \\
85\end{array}$} \\
\hline Sex & Male & & \\
\hline הed & Female & 48 & 15 \\
\hline \multirow{4}{*}{ Age gradation } & $\geq 20$ years & 9 & 3 \\
\hline & $21-40$ years & 166 & 52 \\
\hline & $4 I-60$ & 119 & 37 \\
\hline & $\leq 6$ lyears & 28 & 8 \\
\hline \multirow{5}{*}{ Education } & Illiterate & 18 & 6 \\
\hline & Khalwa & 85 & 14 \\
\hline & Basic & 42 & 25 \\
\hline & Secondary & 118 & 35 \\
\hline & university and above & 63 & 20 \\
\hline \multirow{3}{*}{ type of land owner ship } & Owner & 206 & 64 \\
\hline & Renter & 76 & 24 \\
\hline & Participate with other & 40 & 12 \\
\hline
\end{tabular}


Table Continued...

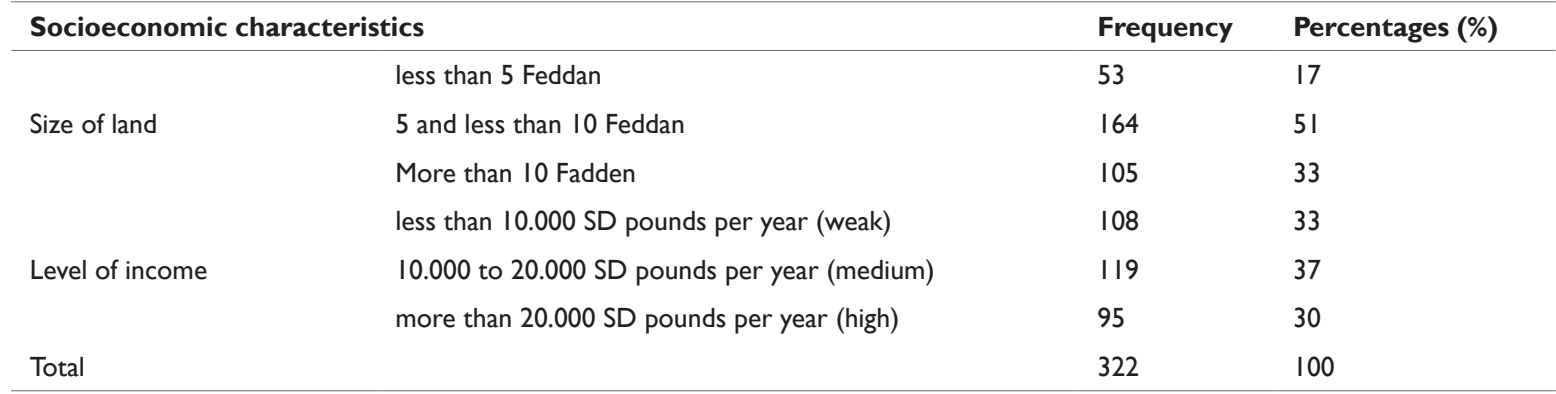

Indicating by SPSS; descriptive statistic, Source; field research 2016

To induce farmers to adopt a productive new agricultural technology, we apply simple and complex contagion diffusion models. ${ }^{15}$ The results indicated that of the respondents $70 \%$ there agricultural experience less than 15 years, while $30 \%$ there experience more than 15 years that means the responder includes high and low agricultural experience. the receipt of extension Agricultural experience increases farm income had more effect in the agricultural investment. ${ }^{16}$ Results showed that $79 \%$ the respondents planted cash crops (cotton, corn, wheat, and peanuts), while $11 \%$ their cultivation vegetable and crops and $10 \%$ cultivation vegetables only, Table 2 that means the farmers interested in cultivation crops which were expensive and had high income for that they in need to more information about this crop to by succeed. Substantial investment in the training of agriculturalists and the further science development of systems simulation is required to tackle the enormous challenges facing agricultural development in the region. ${ }^{17}$

Table 2 Distribution of the respondents according to their agricultural experience and type of crops cultivated

\begin{tabular}{llll}
\hline Experiences and type if crops & Frequency & Percentages (\%) \\
\hline \multirow{4}{*}{ Agricultural experience } & less than 5 years & 88 & 27 \\
& $5-10$ years & 71 & 22 \\
& II - I5 years & 68 & 21 \\
& $16-20$ years & 40 & 13 \\
& More than 20 years & 55 & 17 \\
Types of crops & Crops (cotton, Corn, wheat, peanuts) & 256 & 79 \\
& Vegetables & 32 & 10 \\
Total & vegetables and crops & 34 & 11 \\
\hline
\end{tabular}

Indicating by SPSS; descriptive statistic, Source; field research 2016

Regarding source of seed, the results revealed that $50 \%$ of the respondents their main sources of seeds were the service centers, $36 \%$ of them access seeds from other farmers and $14 \%$ from the extension. While the source of fertilizers, $76 \%$ of the respondents their source was service centers, $13 \%$ accessed from farmers and only $11 \%$ from the extension. Regarding the source of pesticides, $75 \%$ of the respondents their sources of pesticides was service centers, $13 \%$ accessed from and $12 \%$ from extension, Table 3, this agrees with ${ }^{18}$ Which reported that from 1992 the privet sectors was the main input suppliers, also few of farmers still used traditional input suppliers like farmers to farmer exchanged and very few farmers dependence on extension as their input suppliers and that mean extension was very weak as input source.

Table 3 Distribution of the respondents by their sources of inputs

\begin{tabular}{llll}
\hline Sources of inputs & & Frequency & Percentages (\%) \\
\hline \multirow{3}{*}{ Source of Seed } & Extension & 44 & 14 \\
& service centers & 161 & 50 \\
& Farmers & 117 & 36 \\
Source of Fertilizers & Extension & 35 & 11 \\
& service centers & 246 & 76 \\
Source of Pesticides & Farmers & 41 & 13 \\
& Extension & 37 & 12 \\
Total & service centers & 243 & 75 \\
& Farmers & 42 & 13 \\
\hline
\end{tabular}

Indicating by SPSS; descriptive statistic, Source; field research 2016 
The knowledge score of participants increased as the number of information sources contacted increased. ${ }^{19}$ The results in a Table 4 indicated the source of information regarding to production inputs, for improving seeds information: the high percentage of $45 \%$ of the respondents accessed from service centres, $32 \%$ of them from other farmers and only $23 \%$ of the respondents received from the extension. For fertilizers information $68 \%$ of the respondents received from service centres, $19 \%$ of them got from others farmers, and only $13 \%$ from the extension. Also for pesticides information, $71 \%$ of the respondents their source of pesticides information were service centres, $17 \%$ of the other farmers represent the source of information and $12 \%$ of the respondent's extension was the pesticides information source. When the source of modern equipment information results revealed that $57 \%$ of the respondents their source of modern equipment information were service canters, $27 \%$ of them their sources were other farmers and $16 \%$ their source was an extension, Table 4. Competing models of innovation informing agricultural extension, such as transfer of technology, participatory extension, and technology development, and innovation systems have been proposed over the last decades. ${ }^{20}$

Table 4 Distribution of the respondents according to the sources of information

\begin{tabular}{llll}
\hline Sources of information about the inputs & Frequency & Percentages (\%) \\
\hline \multirow{3}{*}{ Improving seeds information } & Extension & 74 & 23 \\
& service centers & 144 & 45 \\
& Farmers & 104 & 32 \\
Fertilizer information & Extension & 41 & 13 \\
& service centers & 218 & 68 \\
Pesticides information & Farmers & 63 & 19 \\
& Extension & 38 & 12 \\
& service centers & 228 & 71 \\
Modern equipment information & Farmers & 56 & 17 \\
& Extension & 51 & 16 \\
Total & service centers & 184 & 57 \\
\hline
\end{tabular}

Indicating by SPSS; descriptive statistic, Source; field research 2016

Current practices in agricultural management involve the application of rules and techniques to ensure high quality and environmentally friendly production. ${ }^{21}$ The results in Table 5 showed that $40 \%$ of the respondents their source of ploughing information were services centres, $35 \%$ of them got from others farmers and only $25 \%$ from extension. For source of preparing land information 51\% of the respondents their source were other farmers, $26 \%$ of them accessed from extension and only $23 \%$ got information from service centres. Also results extend to revealed that $55 \%$ of the respondents their source of time of planting information were other farmers, $26 \%$ of them from the extension and $19 \%$ of them were service centres. In regards to the source of seeding rate information: the high percentages of the respondents $44 \%$ their sources were other farmers, $30 \%$ service centres were and $26 \%$ extension. While the source of irrigation information $44 \%$ their source were other farmers, $34 \%$ extension and $22 \%$ service centres. Also results indicated the source of fertilizer information by $55 \%$ of the respondents their source were service centres, $27 \%$ and $18 \%$ of them their sources other farmers and extension respectively.The above result agreed with ${ }^{22}$ who mentioned farmers that reported receipt of "very useful" agricultural advice had greater productivity and greater food security compared to those that reported receipt of advice that they considered not useful and those that did not receive any advice at all.
The results in Table 6 shows the links with the agricultural partners: All of the respondent's replied that they had no links with research centres, university and imported companies as partners in agricultural work. But they explained that they had link with extension and ASCs as partners in agricultural work as $46 \%$ of the respondents their link with extension and assessed as strong, $18 \%$ assess as weak $30 \%$ assess as none and $6 \%$ assess as very strong. When $71 \%$ of the respondent their link with ASCs and assessed as strong, 16\% assess as weak $8 \%$ assess as none and $5 \%$ assess as very strong link.

Different tools in delivering extension messages enable more information exchange among agriculture stakeholders and this increase agricultural production and agribusiness..$^{23}$ The results of the study indicate the methods used by agricultural extension and depicted that $62 \%$ of the respondents reported that the personal explanation was common methods used by the extension agent, $30 \%$ of them indicate that no visits, $5 \%$ indicated both personal explanation and demonstration field, and 3\% addressed both the methods was media bulletins. On the other hand methods used by service centres $92 \%$ of the respondents cited the personal explanation and $8 \%$ no visits conducted, Table 7 . This result in line with $^{24}$ he reported that extension often depend in complex ways in delivering new technology or information for improving the farming system. 
Table 5 Distribution of the respondents by their sources of technical packages

\begin{tabular}{|c|c|c|c|}
\hline \multicolumn{2}{|c|}{ Sources of technical packages } & \multirow{2}{*}{$\begin{array}{l}\text { Frequency } \\
80\end{array}$} & \multirow{2}{*}{$\begin{array}{l}\text { Percentages (\%) } \\
25\end{array}$} \\
\hline & Extension & & \\
\hline \multirow[t]{3}{*}{ Method of plowing } & service centers & 128 & 40 \\
\hline & Farmers & 114 & 35 \\
\hline & Extension & 84 & 26 \\
\hline \multirow[t]{3}{*}{ Preparing land } & service centers & 75 & 23 \\
\hline & Farmers & 163 & 51 \\
\hline & Extension & 84 & 26 \\
\hline \multirow[t]{3}{*}{ Time of planting } & service centers & 62 & 19 \\
\hline & Farmers & 176 & 55 \\
\hline & Extension & 82 & 26 \\
\hline \multirow[t]{3}{*}{ Seeding rate } & service centers & 98 & 30 \\
\hline & Farmers & 142 & 44 \\
\hline & Extension & 108 & 34 \\
\hline \multirow[t]{3}{*}{ Irrigation } & service centers & 73 & 23 \\
\hline & Farmers & $|4|$ & 43 \\
\hline & Extension & 57 & 18 \\
\hline \multirow[t]{2}{*}{ Fertilization } & service centers & 177 & 55 \\
\hline & Farmers & 88 & 27 \\
\hline Total & & 322 & 100 \\
\hline
\end{tabular}

Indicating by SPSS; descriptive statistic, Source; field research 2016

Table 6 Distribution of the respondents by their links with the agricultural partners

\begin{tabular}{|c|c|c|c|}
\hline \multicolumn{2}{|c|}{ The links with the agricultural partners } & \multirow{2}{*}{$\begin{array}{l}\text { Frequency } \\
322\end{array}$} & \multirow{2}{*}{$\begin{array}{l}\text { Percentages (\%) } \\
100\end{array}$} \\
\hline links with research centers & none (no visits in the season) & & \\
\hline links with university & none (no visits in the season) & 322 & 100 \\
\hline links with imported companies & none (no visits in the season) & 322 & 100 \\
\hline \multirow[t]{6}{*}{ links with extension } & very strong (more than 5 visits in the season) & 20 & 6 \\
\hline & strong (3-5 visits in the season) & 147 & 46 \\
\hline & weak (less than 3 visits in the season) & 58 & 18 \\
\hline & none (no visits in the season) & 97 & 30 \\
\hline & very strong (more than 5 visits in the season) & 17 & 5 \\
\hline & strong (3-5 visits in the season) & 228 & 71 \\
\hline \multirow{2}{*}{ links with service centers } & weak (less than 3 visits in the season) & 50 & 16 \\
\hline & none (no visits in the season) & 27 & 8 \\
\hline Total & & 322 & 100 \\
\hline
\end{tabular}

Indicating by SPSS; descriptive statistic, Source; field research 2016

Citation: Ali AEM,Abdallh MAA, Hamad MAA.Assessment of the components that deliver agricultural extension services, at Gezira state-wad medani great locality, Sudan. MOJ Eco Environ Sci. 2020;5(2):49-60. DOI: I0.15406/mojes.2020.05.00I76 
Table 7 Distribution of the respondents by methods of delivering messages

\begin{tabular}{|c|c|c|c|}
\hline \multicolumn{2}{|l|}{ Methods of delivering messages } & \multirow{2}{*}{$\begin{array}{l}\text { Frequency } \\
93\end{array}$} & \multirow{2}{*}{$\begin{array}{l}\text { Percentages (\%) } \\
30\end{array}$} \\
\hline \multirow{4}{*}{$\begin{array}{l}\text { Presentation in case of visits used } \\
\text { by agricultural extension }\end{array}$} & no visits & & \\
\hline & personal explanation & 200 & 62 \\
\hline & Media bulletins & 10 & 3 \\
\hline & personal explanation and demonstration field & 19 & 5 \\
\hline \multirow{2}{*}{$\begin{array}{l}\text { Presentation in case of visits used } \\
\text { by service centers }\end{array}$} & no visits & 27 & 8 \\
\hline & personal explanation & 295 & 92 \\
\hline Total & & 322 & 100 \\
\hline
\end{tabular}

Indicating by SPSS; descriptive statistic, Source; field research 2016

The results of the study indicated that $43 \%, 34 \%$, and $23 \%$ of the respondents reported that the most quick response to farmers needs services centres, extension and other farmers respectively. Also results extend to revealed that $46 \%, 43 \%$, and only $11 \%$ of the respondents addressed the extension, service centres and other farmers were the less cost in term of services accessibility.
Regarding to the most useful information and availability $45 \%$ of the respondents convinced that extension and service centres present useful information, $52 \%$ of them reported service centres were more available partners. Also results showed that $47 \%$ and $(52 \%)$ of the respondents explained that extension was the more relevant and interested partners on feedback respectively, Table 8.

Table 8 effectiveness partners from beneficiaries point of views

\begin{tabular}{|c|c|c|c|}
\hline The effective partners & & Frequency & Percentages (\%) \\
\hline \multirow{3}{*}{ The quick response partners } & Extension & 110 & 34 \\
\hline & service centers & 139 & 43 \\
\hline & Farmers & 73 & 23 \\
\hline \multirow{3}{*}{ The less cost } & Extension & 148 & 46 \\
\hline & service centers & 138 & 43 \\
\hline & Farmers & 36 & II \\
\hline \multirow{3}{*}{ The most useful information } & Extension & 145 & 45 \\
\hline & service centers & 145 & 45 \\
\hline & Farmers & 32 & 10 \\
\hline \multirow{3}{*}{ The more available partners } & Extension & 126 & 39 \\
\hline & service centers & 168 & 52 \\
\hline & Farmers & 28 & 9 \\
\hline \multirow{4}{*}{ The more relevant partners } & Extension & 152 & 47 \\
\hline & service centers & $|4|$ & 44 \\
\hline & Farmers & 15 & 5 \\
\hline & no one & 14 & 4 \\
\hline \multirow{3}{*}{ The interested partners on feedback } & Extension & 168 & 52 \\
\hline & service centers & 140 & 43 \\
\hline & no one & 14 & 5 \\
\hline Total & & 322 & 100 \\
\hline
\end{tabular}

Indicating by SPSS; descriptive statistic, Source; field research 2016 


\section{Results of correlation and regression analysis}

The results of correlation test showed that there was some Personal characteristic had significantly correlated with links with other agricultural partners, there are; The owner type and the link with extension (.006) the value of $\mathrm{R}=-.153$, the agricultural experience and the link with the extension (.002) the value of $\mathrm{R}=.169$ and the plant type had significant correlation with the relationship with extension (.000) value of $\mathrm{R}=346$, Table 9. The results extend to indicated that there was some significantly correlated between the farmers connectivity with agricultural partners and the source of inputs these are the source of seeds and the link with extension $(.011)$ the value $(\mathrm{R}=-$ $.142)$, the source of fertilizers and the link with extension (.000) the value $(\mathrm{R}=.317)$ while the link with service centers had low significant $(.025)$ the value $(\mathrm{R}=.125)$, the source of pesticides and the link with extension $(.000)$ the value $(\mathrm{R}=.309)$ while the link with service centers had low significant (.038) the value $(\mathrm{R}=.116)$, Table 10 .

Table 9 Distribution of correlation test to measure the relationship between some personal characteristics of the respondents and links with the agricultural partners

\begin{tabular}{|c|c|c|c|c|c|c|}
\hline \multicolumn{2}{|c|}{$\begin{array}{l}\text { Personal characteristics of the } \\
\text { respondents }\end{array}$} & \multirow{2}{*}{$\begin{array}{l}\text { Link with } \\
\text { research } \\
\text { centers }\end{array}$} & \multirow{2}{*}{$\begin{array}{l}\text { Link with } \\
\text { university } \\
\text {.c }\end{array}$} & \multirow{2}{*}{$\begin{array}{l}\text { Link with } \\
\text { imported } \\
\text { companies }\end{array}$} & \multirow{2}{*}{$\begin{array}{l}\text { Link with } \\
\text { extension } \\
\text {-.153** }\end{array}$} & \multirow{2}{*}{$\begin{array}{l}\text { Link with } \\
\text { service } \\
\text { centers }\end{array}$} \\
\hline & Correlation & & & & & \\
\hline \multirow[t]{3}{*}{ Owner Type } & Sig. (2-tailed) & . & . & . & 0.006 & 0.35 \\
\hline & $\mathrm{N}$ & 322 & 322 & 322 & 322 & 322 \\
\hline & Correlation &.$c$ & .c &.$c$ & $.169 * *$ & 0.013 \\
\hline \multirow{3}{*}{$\begin{array}{l}\text { Agricultural } \\
\text { experience }\end{array}$} & Sig. (2-tailed) & . & . & . & 0.002 & 0.811 \\
\hline & $\mathrm{N}$ & 322 & 322 & 322 & 322 & 322 \\
\hline & Correlation &.$c$ &.$c$ &.$c$ & $.346 * *$ & 0.104 \\
\hline \multirow[t]{2}{*}{ Plant types } & Sig. (2-tailed) & . & . & . & 0 & 0.062 \\
\hline & $\mathrm{N}$ & 322 & 322 & 322 & 322 & 322 \\
\hline
\end{tabular}

**. Correlation is significant at the 0.01 level (2-tailed)

*. Correlation is significant at the 0.05 level (2-tailed)

c. Cannot be computed because at least one of the variables is constant

Table 10 Correlation test to measure the relationship between farmer's connectivity with the partners and their source of inputs

\begin{tabular}{|c|c|c|c|c|c|c|}
\hline Source of inputs & & $\begin{array}{l}\text { Link with } \\
\text { research } \\
\text { centers }\end{array}$ & $\begin{array}{l}\text { Link with } \\
\text { university }\end{array}$ & $\begin{array}{l}\text { Link with } \\
\text { imported } \\
\text { companies }\end{array}$ & $\begin{array}{l}\text { Link with } \\
\text { extension }\end{array}$ & $\begin{array}{l}\text { Link with } \\
\text { service } \\
\text { centers }\end{array}$ \\
\hline \multirow{3}{*}{ Source of Seed } & Correlation & a & a & a & $.142 *$ & -0.039 \\
\hline & Sig. (2-tailed) & . & . & . & 0.011 & 0.489 \\
\hline & $N$ & 322 & 322 & 322 & 322 & 322 \\
\hline \multirow{3}{*}{$\begin{array}{l}\text { Source of } \\
\text { Fertilizers }\end{array}$} & Correlation &. $\mathrm{a}$ &. $\mathrm{a}$ & . a & $.317^{* *}$ & $.125^{*}$ \\
\hline & Sig. (2-tailed) & . & . & . & 0 & 0.025 \\
\hline & $N$ & 322 & 322 & 322 & 322 & 322 \\
\hline \multirow{3}{*}{ Source of Pesticides } & Correlation &. $\mathrm{a}$ & a &. $\mathrm{a}$ & $.309 * *$ & $.116^{*}$ \\
\hline & Sig. (2-tailed) & . & . & . & 0 & 0.038 \\
\hline & $N$ & 322 & 322 & 322 & 322 & 322 \\
\hline
\end{tabular}

**. Correlation is significant at the 0.01 level (2-tailed)

*. Correlation is significant at the 0.05 level (2-tailed)

c. Cannot be computed because at least one of the variables is constant

The results in Table 11 revealed that link with extension had high significant correlation with all technical package; improving seeds information (.000) the value $(\mathrm{R}=.312)$, new fertilizer information $(.000)$ the value $(\mathrm{R}=.349)$, pesticides information $(.000)$ the value $(\mathrm{R}=.384)$, method of plowing information (.000) the value $(\mathrm{R}=.396)$,

modern equipment information $(.000)$ the value $(\mathrm{R}=.365)$, Time of planting information (.000) the value $(\mathrm{R}=.294)$, preparing land information $(.000)$ the value $(\mathrm{R}=.399)$, seeding information $(.000)$ the value $(\mathrm{R}=.396)$, irrigation information $(.000)$ the value $(\mathrm{R}=.388)$, used of fertilization information (.000) the value $(\mathrm{R}=.348)$ and used 
of pesticides information (.000) the value $(\mathrm{R}=.271)$. While the link with service centers had a significant correlation with new fertilizer information(.014) the value $(\mathrm{R}=.137)$ and pesticides information
(.015) the value $(\mathrm{R}=.136)$ while the other application information had no significant correlation with the link with service centers.

Table I I Correlation test to measure the relationship between farmers links with the partners and the technical package

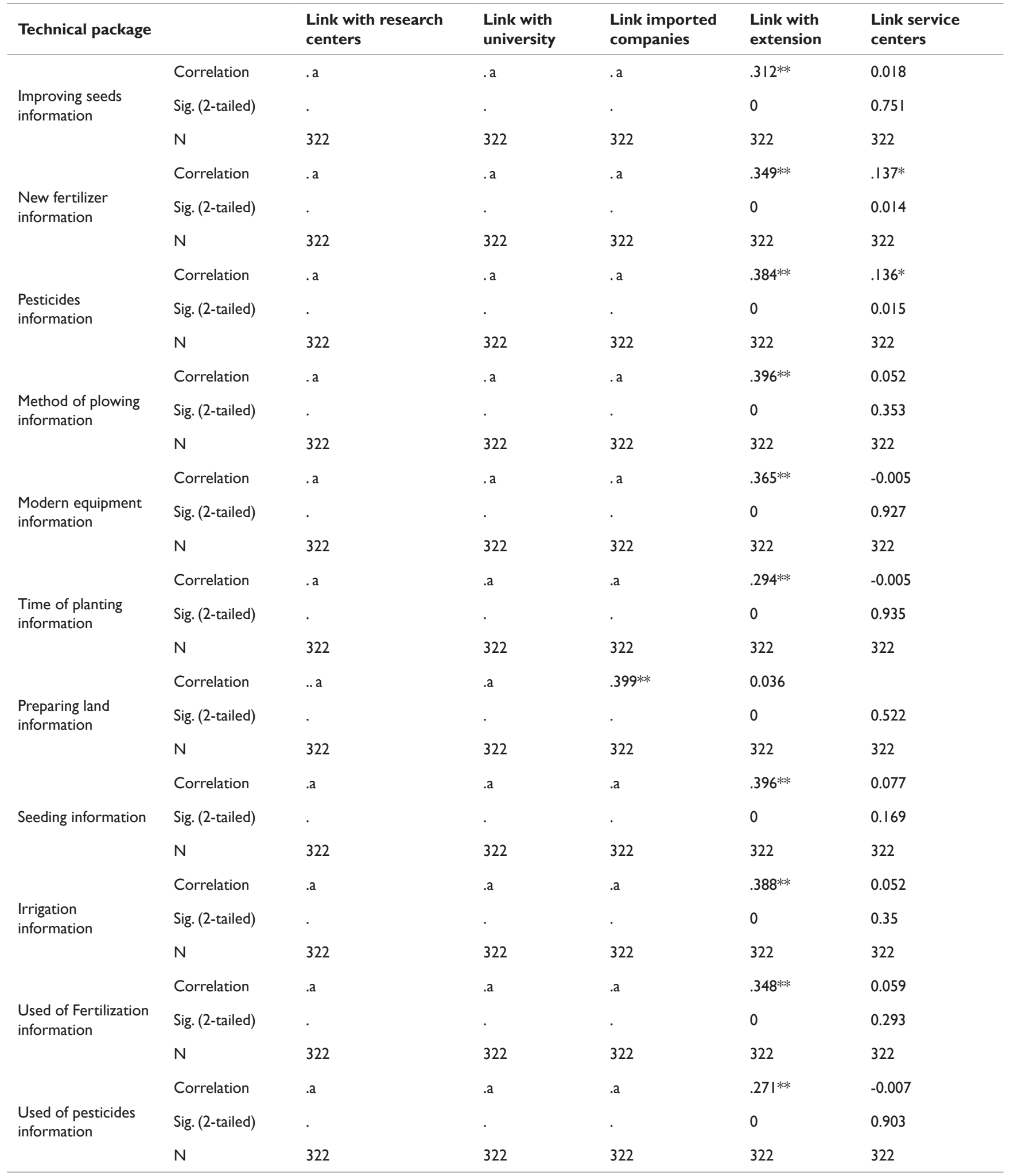

**. Correlation is significant at the 0.01 level (2-tailed)

*. Correlation is significant at the 0.05 level (2-tailed)

c. Cannot be computed because at least one of the variables is constant

Citation: Ali AEM,Abdallh MAA, Hamad MAA.Assessment of the components that deliver agricultural extension services, at Gezira state-wad medani great locality, Sudan. MOJ Eco Environ Sci. 2020;5(2):49-60. DOI: I0.15406/mojes.2020.05.00I76 
Also, the results depicted that link with extension had high significant correlation with all farmers opinions (First component you go to in case of problem (.000) the value $(\mathrm{R}=.487)$, The first responsive of the components (.000) the value $(\mathrm{R}=.509)$, Components had less cost and efforts to get information (.000) the value $(\mathrm{R}=.561)$, The components had the required information (.000) the value $(\mathrm{R}=.494)$, The more relevant components $(.000)$ the value $(\mathrm{R}=.466)$, The interested components in get and register the comment-feedback $(.000)$ the value $(\mathrm{R}=.389)$, Opinion on add the service centers in the extension models $(.000)$ the value $(\mathrm{R}=.506)$.

When the link with service centers had high significant correlation only with the first responsive of the components (.003) the value $(\mathrm{R}=.164)$ and components had less cost and efforts to get information (.010) the value $(\mathrm{R}=.143)$. Low significant with the First component you go to in case of problem $(.026)$ the value $(\mathrm{R}=.124)$, the components had the required information (.000) the value $(\mathrm{R}=.028)$, opinion on adding the service centers in the extension models (.000) the value $(\mathrm{R}=.043)$, the opinion of the other had no significant correlation with the relationship with service centers, Table 12 .

The results of the regression test measure the effectiveness of the link between the partners and the farmers on the information exchanging, two partners had impact in transferring information to the farmers, one the link with the extension the effective value was (.487 beta) with high significant regression and the second partners had to impact in transferring information is the link with the service centers the effective value was (.450 beta) with low significant regression, Table 13.

Table 12 Correlation test to measure the relationship between farmer's opinions and links with the partners

\begin{tabular}{|c|c|c|c|c|c|c|}
\hline Opinion of the farmers & & $\begin{array}{l}\text { Link with } \\
\text { research centers }\end{array}$ & $\begin{array}{l}\text { Link with } \\
\text { university }\end{array}$ & $\begin{array}{l}\text { Link with imported } \\
\text { companies }\end{array}$ & $\begin{array}{l}\text { Link with } \\
\text { extension }\end{array}$ & $\begin{array}{l}\text { Link with } \\
\text { service centers }\end{array}$ \\
\hline \multirow{3}{*}{$\begin{array}{l}\text { First component you go } \\
\text { to in case of problem }\end{array}$} & Correlation & a &. $\mathrm{a}$ &. $\mathrm{a}$ & $.487 * *$ & $.124 *$ \\
\hline & Sig. (2-tailed) & . & . & . & 0 & 0.026 \\
\hline & $\mathrm{N}$ & 322 & 322 & 322 & 322 & 322 \\
\hline \multirow{3}{*}{$\begin{array}{l}\text { The first responsive of } \\
\text { the components }\end{array}$} & Correlation & a & . a & . a & $.509 * *$ & $.164 * *$ \\
\hline & Sig. (2-tailed) & . & . & . & 0 & 0.003 \\
\hline & $\mathrm{N}$ & 322 & 322 & 322 & 322 & 322 \\
\hline \multirow{3}{*}{$\begin{array}{l}\text { Components had less } \\
\text { cost and efforts to get } \\
\text { information }\end{array}$} & Correlation & a & . a & . a & $.56 I^{* *}$ & $.143 * *$ \\
\hline & Sig. (2-tailed) & . & . & . & 0 & 0.01 \\
\hline & $\mathrm{N}$ & 322 & 322 & 322 & 322 & 322 \\
\hline \multirow{3}{*}{$\begin{array}{l}\text { The components had the } \\
\text { required information }\end{array}$} & Correlation & a & . a & . a & $.494 * *$ & $.122 *$ \\
\hline & Sig. (2-tailed) & . & . & . & 0 & 0.028 \\
\hline & $\mathrm{N}$ & 322 & 322 & 322 & 322 & 322 \\
\hline \multirow{3}{*}{$\begin{array}{l}\text { The more relevant } \\
\text { components }\end{array}$} & Correlation &. $\mathrm{a}$ &. $\mathrm{a}$ &. $\mathrm{a}$ & $.466 * *$ & 0.088 \\
\hline & Sig. (2-tailed) & . & . & . & 0 & 0.116 \\
\hline & $\mathrm{N}$ & 322 & 322 & 322 & 322 & 322 \\
\hline \multirow{3}{*}{$\begin{array}{l}\text { The interested } \\
\text { components in get and } \\
\text { register the comment- } \\
\text { feedback }\end{array}$} & Correlation & a & a & a & $.389 * *$ & -0.054 \\
\hline & Sig. (2-tailed) & . & . & . & 0 & 0.331 \\
\hline & $\mathrm{N}$ & 322 & 322 & 322 & 322 & 322 \\
\hline \multirow{3}{*}{$\begin{array}{l}\text { Opinion on add the } \\
\text { service centers in the } \\
\text { extension models }\end{array}$} & Correlation & a &.$a$ & . a & $.506 * *$ & $.113 *$ \\
\hline & Sig. (2-tailed) & . & . & . & 0 & 0.043 \\
\hline & $\mathrm{N}$ & 322 & 322 & 322 & 322 & 322 \\
\hline
\end{tabular}

**. Correlation is significant at the 0.01 level (2-tailed)

*. Correlation is significant at the 0.05 level (2-tailed)

c. Cannot be computed because at least one of the variables is constant 
Table I 3 Distribution of regression test to measure the effective of the link between the farmers and other partners on information exchanging

\begin{tabular}{|c|c|c|c|c|c|c|}
\hline \multirow{2}{*}{\multicolumn{2}{|c|}{ Model }} & \multicolumn{2}{|c|}{ Unstandardized coefficients } & \multirow{3}{*}{$\begin{array}{l}\text { Standardized Coefficients } \\
\text { Beta }\end{array}$} & \multirow{3}{*}{$\begin{array}{l}\mathbf{T} \\
26.649\end{array}$} & \multirow{3}{*}{$\begin{array}{l}\text { Sig. } \\
0\end{array}$} \\
\hline & & \multirow{2}{*}{$\begin{array}{l}\text { B } \\
3.616\end{array}$} & \multirow{2}{*}{$\begin{array}{l}\text { Std. Error } \\
0.136\end{array}$} & & & \\
\hline I & (Constant) & & & & & \\
\hline & Link with extension & 0.339 & 0.034 & 0.487 & 9.865 & 0 \\
\hline & Link with service centers & $0.04 I$ & 0.048 & 0.45 & 0.845 & 0.039 \\
\hline
\end{tabular}

a. Dependent Variable:The components had the required information

b. Predictors: (Constant), Relationship with service centers, Relationship with extension

This proposed relation between the component had been designing from the reality of the agricultural work whereas a lot of partners had talked their place like the imports companies and the services centers which had found since 1992, the component involving all the agricultural partners, all these partners will be more effective because they in clear and official links with each other represents as teamwork, series to give effective delivery of information to farmers i.e. (adequate, updated recommended information, in the right time, by the best methods, with less costs to increase the best profit for all), as follows in Figure 2 below:

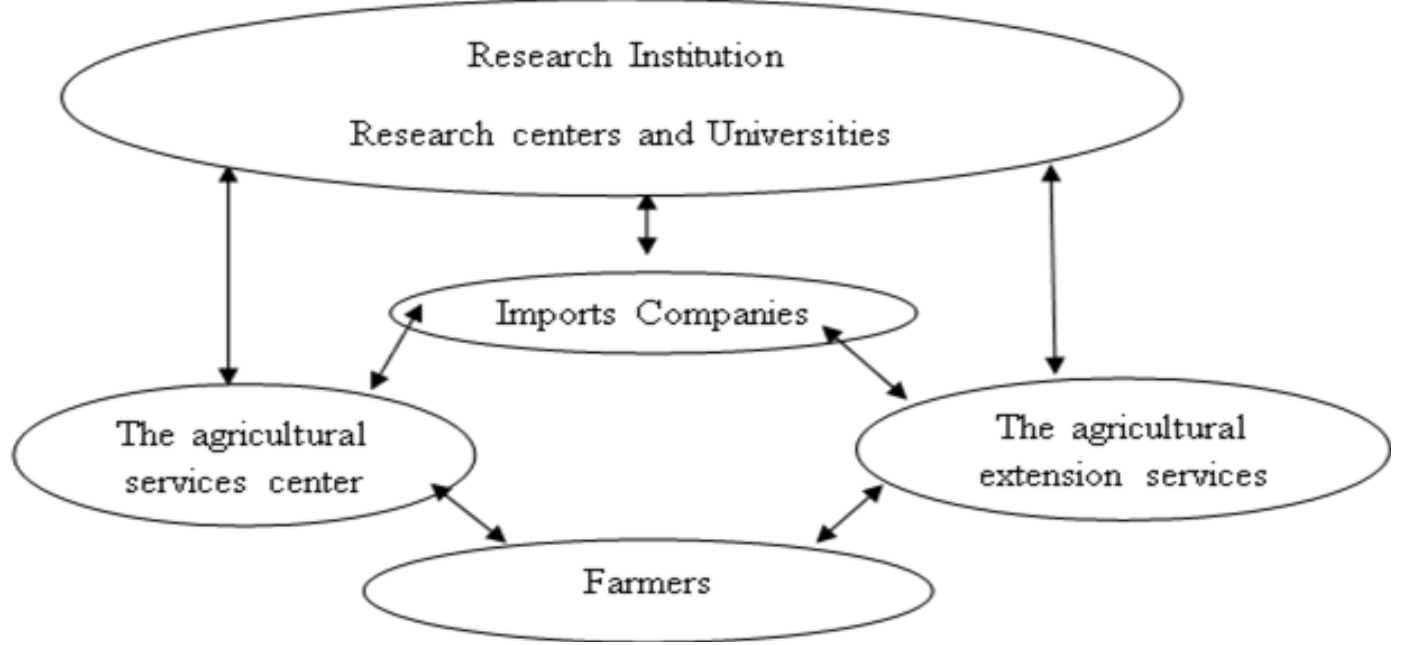

Figure 2 the components for the delivery of agric. services.

\section{Conclusion and recommendations}

The goal of agricultural extension professionals is to influence development change in the societies where they work. Any change will happen when good relationships are formed. A farmer interested in cultivation crops which were expensive and had high income for that they in need the best information from the best source to succeed in his farm management and investment to rich high income. Service centres and extension were the main source of inputs and technical packages to the farmers and had a strong links as agricultural partners. Personal explanations and visits were the frequent methods to deliver information from the services centre and extension. The extension was the less cost, more relevant partners and the interested partners on feedback, while service centres were the quick response and the more available and the explained about the most useful information had been communiqué between extension and service centres, if they put to gathers in one system for sure will be more active. The variables tested showed significantly correlated.

Based on the finding some recommendations were set such as focusing on policy and strategy that encourages the development of the extension system, training sessions have to be held to promote extension workers, extension officers, and service centers workers, using more than one approach for conducting extension process, and
Imported companies should make clear links with all agricultural partners.

\section{Acknowledgments}

None.

\section{Funding}

None.

\section{Conflicts of interest}

The author declares no conflict of interest.

\section{References}

1. Lopokoiyit M, Onyango C, Kibett JK. Extension management competency needs of agricultural extension agents in Kenya. Mediterranean Journal of Social Sciences. 2013.

2. Gemo H, Eicher CK, Teclemariam S. Mozambique's experience in building a national extension system. East Lansing, USA: Michigan State University Press; 2005.

3. De Rosa M, Bartoli L, La Rocca G. Testing extension services through AKAP models. Journal of Agricultural Education and Extension. 2014;20(5):513-535. 
4. Hussain SS, Byerlee D, Heisey PW. Impacts of the training and visit extension system on farmers' knowledge and adoption of technology: Evidence from Pakistan. Agricultural Economics. 1994;10(1):39-47.

5. Eicher CK. Agricultural extension in Africa and Asia. Literature review prepared for the World AgInfo Project. Ithaca, New York, USA: Cornell University; 2007

6. Nelson R, Orrego R, Ortiz O, et al. Working with resource-poor farmers to manage plant diseases. Plant Disease. 2001;85(7):684-695.

7. Kenmore P. Integrated pest management. International Journal of Occupational \& Environmental Health. 2002;8(3):173-174.

8. Wellard K, Rafanomezana J, Nyirenda M, et al. A review of community extension approaches to innovation for improved livelihoods in Ghana, Uganda and Malawi. Journal of Agricultural Education and Extension. 2013;19(1):21-35.

9. Veisi H, Liaghati H, Alipour A. Developing an ethics-based approach to indicators of sustainable agriculture using analytic hierarchy process (AHP). Ecological Indicators. 2016;60:644-654.

10. Davis KE. Extension in sub-saharan Africa: overview and assessment of past and current models, and future prospects. Journal of International Agricultural and Extension Education. 2008.

11. Gezira locality, annual report 2016. Gezira State, Sudan; 2016

12. Altae Iman Hassan. How determine sample size. Faculty of Education, Iraq: University of Bagdad; 2012.

13. Khan A, Pervaiz U, Khan NM, et al. Effectiveness of demonstration plots as extension method adopted by AKRSP for agricultural technology dissemination in District Chitral. Sarhad Journal of Agriculture. 2009;25(2):313-320.

14. Hunt W, Birch C, Vanclay F, et al. Recommendations arising from an analysis of changes to the Australian agricultural research, development and extension system. Food Policy. 2014;44:129-141.
15. Beaman LA, BenYishay A, Magruder J, et al. Can network theory-based targeting increase technology adoption? SSRN Electronic Journal. 2018.

16. Cunguara B, Moder K. Is agricultural extension helping the poor? evidence from rural mozambique. Journal of African Economies. 2011;20(4):562-595.

17. Whitbread AM, Robertson MJ, Carberry PS, et al. How farming systems simulation can aid the development of more sustainable smallholder farming systems in southern Africa. European Journal of Agronomy. 2010;32(1):51-58.

18. Kahan D. The role of the FARM MANAGEMENT SPECIALIST in extension. Rome: FAO; 2013

19. Stringer A, Christley R, Bell C, et al. Associations between sources of information and animal health knowledge of rural farmers in central Ethiopia. International Journal of Agricultural Extension. 2019.

20. Friederichsen R, Minh TT, Neef A, et al. Adapting the innovation systems approach to agricultural development in Vietnam: Challenges to the public extension service. Agriculture and Human Values. 2013;30:555-568.

21. del Águila IM, Cañadas J, Túnez S. Decision making models embedded into a web-based tool for assessing pest infestation risk. Biosystems Engineering. 2015;133:102-115.

22. Ragasa C, Mazunda J. The impact of agricultural extension services in the context of a heavily subsidized input system: The case of Malawi. World Development. 2018;105:25-47.

23. Mtega WP, Msungu AC. Using information and communication technologies for enhancing the accessibility of agricultural information for improved agricultural production in Tanzania. Electronic Journal of Information Systems in Developing Countries. 2013;56(1).

24. Pannell DJ. On the estimation of on-farm benefits of agricultural research. Agricultural Systems. 1999;61(2):123-134. 